\title{
フェムト秒レーザを用いた透明材料の 接合技術* \\ Welding and Joining between Transparent Materials with Femtosecond Lasers
}

\section{渡邊 歴** 玉木隆幸*** \\ Wataru WATANABE and Takayuki TAMAKI}

Key words femtosecond laser, ultrashort laser pulse, welding, joining, glass, hermetic seal

\section{1. 緒言}

耐熱性, 気密性に優れ, 微細な封止技術を開発するため には，低温プロセスまたは熱影響の少ない精密接合技術が 必要である。レーザ接合は非接触で微細な接合が可能であ る. また, パルス幅がピコ秒からフェムト秒オーダーの超 短パルスレーザは物質表面や内部の微細な加工が可能であ

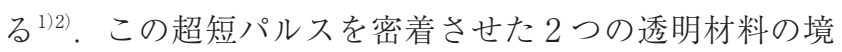
界面に集光照射すれば, レーザパルスの波長に対して吸収 がない材料を直接接合できる ${ }^{3)}$ ）。本稿では，超短パルス レーザ接合の基本原理を概説し，ガラスをはじめとした透 明材料間の接合, および, 透明材料と金属や半導体との接 合に関する原理と研究動向について述べる.

\section{2.レーザ接合}

レーザ接合法は，（1）熱変形が少なく高強度，（2）非接 触で特殊な䨌囲気が不要, (3) 高速な接合が可能, (4) 微 細領域の接合が可能という特徵をもつ。しかし、レーザ接 合法は媒質の線形吸収現象による熱発生を用いるため, レ 一ザ光が照射される全領域にわたり被接合材料の溶融が生 じることになる，例えば，図１（a）のように透明材料と 吸収材料が重㸚合わせられているとき，レーザ光は透明材 料を透過後, 吸収材料にて線形吸収される。このため, レ 一ザ光が照射される吸収材料の全領域にわたり線形吸収が 生じ, 熱が発生する。そして, 被接合材料の溶融が生じる ことにより，2つの材料を接合することができる。また は, 図 1 (b) の上うに, 透明材料間に吸収材料が中間層 として介在されている場合，中間層において線形吸収によ る熱が発生し，材料が溶融し， 2 つの材料を接合すること ができる.しかし，被接合材料や中間層として用いる材料 は，レーザ波長に対して吸収する材料を選択しなければな らず，材料の種類に制限があることになる。この線形吸収 を用いることにより，例えば $\mathrm{CO}_{2}$ レーザ（波長 10 ミクロ

"原稿受付 平成 27 年 5 月 20 日

*立命館大学理工学部（滋賀県草津市野路東 1-1-1）

**大奈良工業高等専門学校（奈良県大和郡山市矢田町 22 番地）
ン）やYAG レーザ（波長 1 ミクロン）を用いた，ガラス 間の接合やガラスとシリコン間の接合が報告されている.

\section{3. 超短パルスレーザ接合}

\section{1 超短パルスレーザによるガラス内部加工}

パルスレーザにおいて，レーザが発振している時間の幅 をパルス幅という，また，ピコ秒からフェムト秒というご く短いパルス幅をもつレーザを超短パルスレーザと称して いる.ささらに, パルス幅が数百フェムト秒以下のパルスレ 一ザをフェムト秒レーザと称している。 フェムト秒レーザ ではパルスの持続時間がきわめて短く, 光エネルギーが閉 じ达められる. 図 2 にパルスレーザのパルス列とパルス 幅との関係を示す。フェムト秒レーザではパルス列が繰り 返し発振され, このパルス列の時間間隔の逆数, すなわ ち, 光源の繰り返し周波数は重要なレーザ加工因子とな る.このような超短パルスレーザからのパルス列をガラス などの透明材料内部へ集光照射すれば, 集光点近傍の微小 領域において局所的な内部加工を実現することができる. 通常のレーザでは, 物質と光との相互作用は電界に比例し た線形光学による影響のみがほとんどである。一方, 超短 パルスレーザでは，パルス幅が短いためピーク強度が高く なる。このため超短パルスレーザでは電界の二乗, 三乗な どに対応した非線形光学過程が寄与するのが特徵である. また, 超短パルスレーザでは, 電子振動から格子振動への フォノンカップリングが起きる前にレーザーパルスの照射 が終了するため, 熱が拡散する範囲が限定され, 微小な領 域のみ材料をクラックなしで溶融することができる。レー ザーパルスをガラス内部に集光すると, 集光点近傍の領域 に执いて, 多光子イオン化やトンネルイオン化などの非線 形吸収現象が生じる。この非線形吸収により, 局所的に材 料が溶融され, 局所的な構造変化が誘起されることによ り, 内部加工が実現される ${ }^{122)}$.

ここでは，フェムト秒レーザをガラス内部に集光したと きの加工例を示す. 繰り返し周波数 $1 \mathrm{MHz}$, 中心波長 $1064 \mathrm{~nm}$ ，パルス幅 $250 \mathrm{fs}$ のファイバレーザを用い, レー ザパルスを開口数 0.40 の対物レンズによりホウケイ酸ガ 
(a)

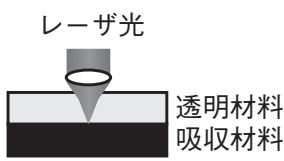

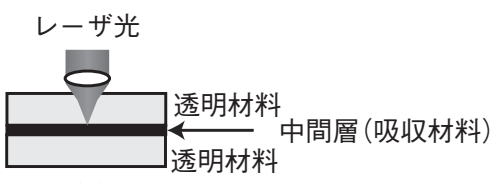

(b)
図 1 レーザを用いた接合原理.（a）線形吸収現象によるレーザ接 合,（b）中間吸収材料を用いたレーザ接合。

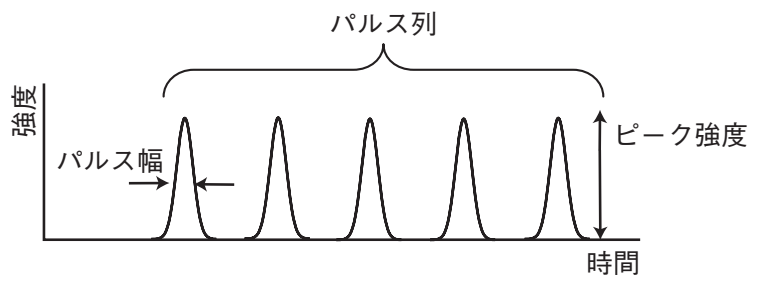

図２パルスレーザのパルス列とパルス幅

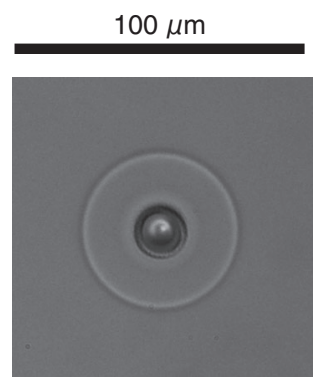

図３フェムト秒レーザパルスをホウケイ酸ガラス内部に集光する ことにより得られた構造変化の透過顕微鏡像

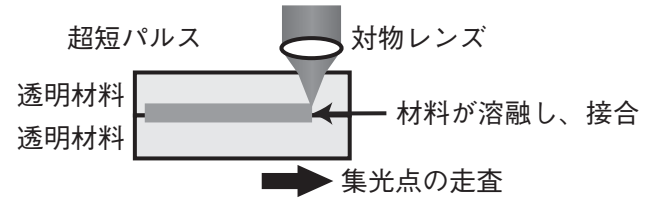

図４フェムト秒レーザを用いた透明材料の接合概念図

ラス表面から深さ $300 \mu \mathrm{m}$ の内部に集光照射する。レーザ の入射強度 $1 \mathrm{~W}$, 露光時間 $1 / 60$ 秒で誘起された構造変化 の透過顕微鏡像を図 3 に示す。レーザパルスをガラス内 部に集光しているため，ガラス表面を傷つけることなく， 材料内部の微細領域のみをクラックが発生することなく溶 融可能であることがポイントである.

\section{2 超短パルスレーザ接合の原理}

超短パルスを透明材料内部に集光すると材料を非接触で かつ局所的に内部加工ができることから，図 4 に示すよ うに，超短パルスを 2 つ基板の境界面に集光することに より，局所的な溶融が生じ， 2 つの基板を接合することが できる ${ }^{7) ~ 10)}$. この接合法は, 高精度, 中間層が不要, 微 細領域の接合が可能という利点をもつ。媒質が透明であれ ば，中間層なしで，2つの透明基板を直接接合できること に特徵がある。しかし，レーザパルスを集光するため，任 意面積を接合するためには，集光点を 2 次元的に走査する 必要がある，また，超短パルスレーザ接合では，基板間の 隙間が大きくなれば基板間でアブレーションが生じ，接合 が不安定になるため，圧力をかけることにより基板間の隙

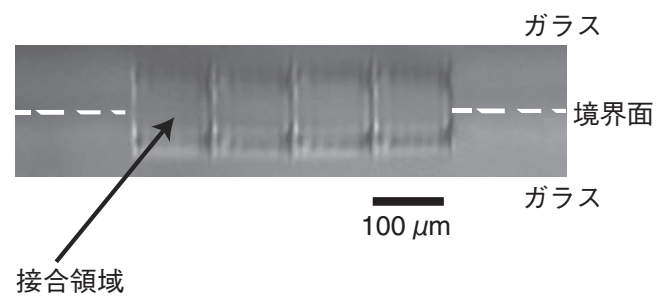

図５フェムト秒レーザを用いたガラスとガラスの接合例

間を低減し，レーザパルスを照射する必要がある。

\section{3 ガラス接合}

超短パルスを用いたガラスとガラス接合の一例を示す. 図 5 は，接合面を含む側面方向から観察した透過顕微鏡 像である ${ }^{9}$. 波長 $800 \mathrm{~nm}$, 繰り返し周波数 $1 \mathrm{kHz}$ ，パルス 幅約 $100 \mathrm{fs}$ の光パルスを集光し, 試料走査により接合領 域を形成した，接合部の引張り強度は約 $15 \mathrm{MPa}$ である. ガラスの接合では, ホウケイ酸ガラス, 石英ガラスなど同 種のガラスだけでなく，異種ガラスの接合も可能であ $3^{7) \sim 11}$. 近年の同種ガラス接合, 異種ガラス接合の報告 例は文献 5）にまとめられている.

\section{4 高分子材料の接合}

熱可塑性のため複雑な形状に加工することが可能であ り,さまざまな光学的用途に用いられている PMMA (polymethyl methacrylate) 材料間のマイクロ接合が報告 されている ${ }^{12}$ 。 また, PMMA 基板はマイクロ流路に用い られるため, 直接接合によるマイクロ流路チップの気密性 封止が試みられている ${ }^{13)}$.

\section{5 ガラスと吸収材料の接合}

超短パルスレーザ接合では透明材料間を中間層なしに溶 接することが一つの大きな利点であるが，図 1（a）で示 したように, 透明材料と吸収材料の微細溶接も可能であ る。レーザパルスは透明材料側では吸収されることなく透 過し，下方の吸収材料との境界面でレーザパルスが集光さ れ, 吸収材料の集光領域のみ線形吸収により材料が溶融 し，溶融した材料が固まることにより接合が実現される。 従来のレーザ溶接と異なり, 熱的な影響が少ないため微細 な接合が可能となる，MEMS や各種センサを作製するた めには，ガラス基板とシリコン基板との気密封止が必要で ある。このため、フェムト秒レーザを用いた，ガラスとシ リコンの接合が報告されている(1415)。 また, 銅などの金属 とガラスの接合が報告されている ${ }^{16)}$ 。さらに，この技術を 応用して, 異なる金属の微細接合も報告されている ${ }^{17)}$.

\section{6 集光点の走查方法}

接合に適した走査方法について検討が行われている. 正 方形状に外部から内部（圧着部）へ（図 6（a)），または， 内部から外部へ試料を走查し（図 6 (b)), 大きさ $2 \mathrm{~mm}$ 四方の正方形内に収まる接合部領域を形成した，接合前に は，超短光パルスレーザ接合時に生じる被接合試料の境界 面に扔ける表面損傷を抑制するために，治具を用いて，試 料境界面に抢ける隙間を局所的に減少させている（図 7). 具体的には，ステンレス平板とレンズが備え付けられたス 


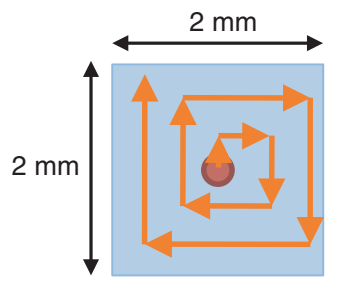

(a) 外部から内部への走査

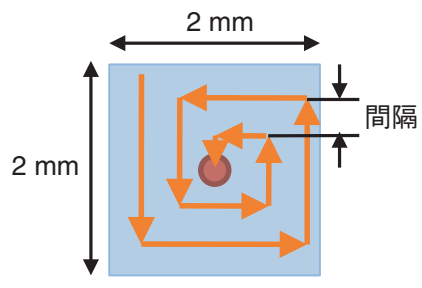

(b) 内部から外部への走査
図 6 走査方法の違いによる接合部領域の検討

表 1 走査方法と接合強度の関係

\begin{tabular}{c|c|c}
\hline 走査方法 & 最大荷重 $[\mathrm{N}]$ & 接合強度 $[\mathrm{MPa}]$ \\
\hline 外部から内部 & 17.4 & 4.35 \\
\hline 内部から外部 & 18.0 & 4.50 \\
\hline
\end{tabular}

内部から次々に接合が行われる

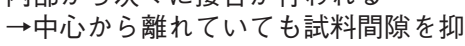
えることが可能 (a) 外部から内部への走査

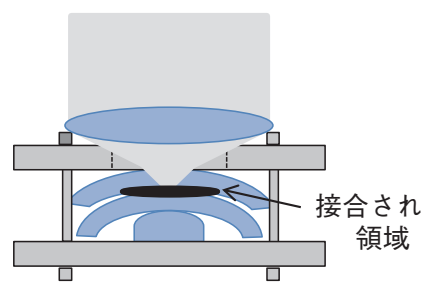

間隙：大 接合が困難

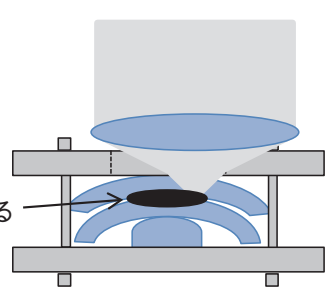

(b) 内部から外部への走査
図 7 レーザパルスの集光点の走査方法による接合領域の差異

テンレス平板との間に試料を配置し，ステンレス平板間に 圧力を加えることにより，レンズ周辺部上の圧着部（密着 部）に拈いて，試料間隙を $100 \mathrm{~nm}$ 以下にしている.

次に，入射パルスエネルギー $0.4 \mu \mathrm{J}$, 溝間隔 $50 \mu \mathrm{m}$ にて 各接合部領域を形成し, 接合された試料に対し引張り試験 を行い, 試料が分離した際の最大荷重掞よび接合強度を求 めた．表 1 より，外部から内部へ向かう走查方法より， 内部から外部へ向かう走查方法の方が高い接合強度が得ら れていることがわかる，これは，図７に示すように，密着 部から離れた点では試料間隙が大きくなるため, 外部から 内部へ向かう走查方法では接合される領域が小さくなり, 周囲からの応力が狭い領域に集中することにより，接合さ れた状態を維持することが困難になるためであると考えら れる，一方，内部から外部へ向かう走查方法では，レンズ により密着された位置から接合が行われるため, 中心から 次々と接合が実現され，レンズから離れた位置であっても 試料間隙を抑えることが可能となり，より低いエネルギー においても接合が実現されると考えられる。このため，外 部から内部へ向かう走查方法よりも, 内部から外部へ向か う走查方法の方がより大きな面積の接合に適しているとい える ${ }^{12)}$. また，集光点の走査を複数回にすることにより， 大面積接合が可能であることが報告されている ${ }^{18)}$.

\section{4. 材料の溶融と接合のメカニズム}

\section{1 熱蓄積と構造変化の大きさとの関係}

レーザパルスをガラス材料に照射したときに熱が発生

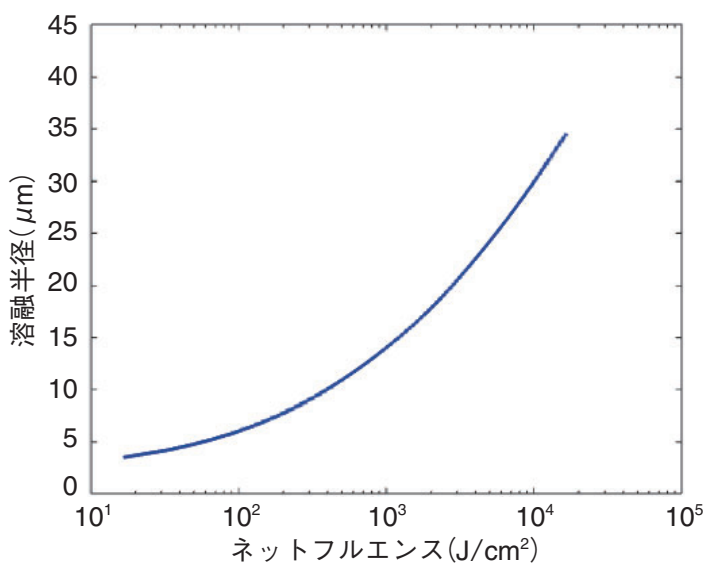

図 $8 \mathrm{AF} 45$ ガラスにレーザーパルスを集光し, 走查加工したときの ネットフルエンスと溶融半径のシミュレーション結果

し，熱の拡散によりガラス材料が局所的に溶融する ${ }^{19)}$.こ の熱の分布，拡散を考えることにより，ガラス材料に扔け る溶融をモデル化できる ${ }^{20)}$. レーザパルス列により累積さ れる熱のダイナミクスを有限差分の熱拡散モデルを用いて シミュレーションする。電子加熱㧍よび電子フォノン結合 の時間は $1 \mathrm{ps}$ 以下であり, ガラス材料を考えた場合，そ の熱拡散時間（1 $\mu \mathrm{s}$ 程度）よりもはるかに短いため,レー ザパルスを熱源と仮定する．集光点の光エネルギーは空間 的にガウス分布とする。熱拡散方程式は次のように表 せる。

$$
\frac{\partial}{\partial r}\left(r^{2} \frac{\partial T}{\partial r}\right)=\frac{r^{2}}{D} \frac{\partial T}{\partial t}
$$

ここで, $r$ は半径方向距離, $T$ は温度, $t$ は時間であり, $D$ は熱拡散係数である。レーザパルスにより瞬間的に温度 上昇が生じ，その後，熱拡散する。レーザの繰り返し周波 数が高い場合は, 熱が拡散する前に, 新たなレーザパルス が到達し，温度が上昇する，空間的に考えれば熱分布はレ 一ザパルスの照射数とともに広がっていくことになる，図 8 にホウケイ酸系無アルカリガラスである AF45 の溶融半 径とネットフルエンスのシミュレーション結果を示す。レ ーザパルスの集光点が走查速度 $v$ で移動すると仮定すれ ば，ネットフルエンスは式(2)で定義される.

$$
N F=\frac{2 w_{0} R}{v} F_{v}
$$

ここで, $F_{v}$ は単一パルスあたりのフルエンスであり, 単 位面積あたりのエネルギー量を表す。また， $w_{0}$ はスポッ トサイズ，Rは繰り返し周波数である。ネットフルエンス は，単一パルスのフルエンスと到達するパルス数の積とな る. 繰り返し周波数は $1 \mathrm{MHz}, 1$ パルスあたりのパルスエ ネルギーを $1 \mu \mathrm{J}$ とすれば, エネルギーは $1 \mathrm{~W}$ となる条件 とした，溶融する最大半径は，材料の溶融温度以上に達し た領域とする。図 8 から，パルス列による熱の蓄積効果に より, 集光点近傍の温度が上昇し, 集光スポットサイズ (約 1 ミクロン) 以上の領域でガラス材料が溶融し, 構造 変化を起こすことができることがわかる，さまざまなガラ 
ス材料におけるシミュレーション結果から, 材料の比熱, 徐冷点が低ければ，材料に熱が蓄積されやすいと考えられ る.

\section{5. 超短パルスレーザ接合の研究動向}

接合の安定性, 大面積接合に向けて, 試料の接合面の洗 浄で試料の密着度の向上, 試料持具の改良が報告されてい

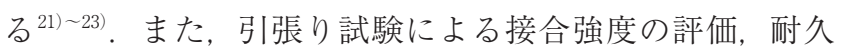
性，リークテストの評価から，実用化に向けた検証が始ま りつつある。これらの技術の応用として, 光ファイバーと ガラスとの接合 ${ }^{24)}$, 太陽電池の封止 ${ }^{25) 26)}$, マイクロ流路 ${ }^{13}$ などへの展開の検討が始まっている.

\section{6. 結言}

超短パルスレーザを用いたレーザ接合について紹介し た。超短パルスレーザ接合は，中間層なしに，ガラス間の 接合が可能である。また，ガラスと金属，ガラスとシリコ ンなどの接合も可能である。超短パルスレーザによる接合 技術は，気密性パッケージング技術に展開され，薄膜太陽 電池，有機ディスプレイ，マイクロ流路などにも応用が期 待されている.

\section{参 考 文 献}

1) K. Itoh, W. Watanabe, S. Nolte and C.B. Schaffer: Ultrafast Processes for Bulk Modification of Transparent Material, MRS Bulletin, 31 (2006) 620.

2) R.R. Gattass and E. Mazur : Femtosecond Laser Micromachining in Transparent Materials, Nature Photonics, 2 (2008) 219.

3）渡邊歴, 太田道春, 伊東一良：フォトニクス産業応用に向けた 超短パルスレーザーマイクロプロセシング, レーザー研究，41 (2013) 780.

4) W. Watanabe, T. Tamaki and K. Itoh : in Femtosecond Laser Micromachining:Photonic and Microfluidic Devices in Transparent Materials, Eds, R. Osellame, G. Cerullo, R. Ramponi, Topics in Applied Physics, Springer, (2012) 467.

5) K. Sugioka and Y. Cheng: Femtosecond Laser Three-dimensional Micro- and Nanofabrication, Appl. Phys. Rev., 1 (2014) 041303.

6) I. Miyamoto, K. Cvecek, Y. Okamoto and M. Schmidt: Internal Modification of Glass by Ultrashort Laser Pulse and Its Application to Microwelding, Appl. Phys. A, 114 (2014) 187.

7) T. Tamaki, W. Watanabe, J. Nishii and K. Itoh: Welding of Transparent Materials Using Femtosecond Laser Pulses, Jpn. J. Appl. Phys., 44 (2005) L687.

8) W. Watanabe, S. Onda, T. Tamaki, K. Itoh and J. Nishii : Spaceselective Laser Joining of Dissimilar Transparent Materials Using Femtosecond Laser Pulses, Appl. Phys. Lett., 89 (2006) 021106 .

9) W. Watanabe, S. Onda, T. Tamaki and K. Itoh : Direct Joining of Silica Glass Substrates by $1 \mathrm{kHz}$ Femtosecond Laser Pulses, Appl. Phys. B, 87 (2007) 85.

10) T. Tamaki, W. Watanabe and K. Itoh: Laser Micro-welding of Transparent Materials by a Localized Heat Accumulation Effect Using a Femtosecond Fiber Laser at 1558 nm, Opt. Express, 14 (2006) 10460

11) J. Bovatsek, A. Arai and C.B. Schaffer: Three-dimensional Micromachining Inside Transparent Materials Using Femtosecond Laser Pulses: New Applications, in CLEO/QELS and PhAST 2006, California, USA, May, (2006).
12）村上智亮, 玉木隆幸, 渡辺歴, 小関泰之, 押田至啓 : 第 58 回応 用物理学関係連合講演会, (2011) 6a-KH-6.

13) A. Volpe, F. Di Niso, C. Gaudiuso, A. De Rosa, R. M. Vázquez, A. Ancona, P.M. Lugarà and R. Osellame : Welding of PMMA by a Femtosecond Fiber Laser, Opt. Express, 23 (2015) 4114.

14) A. Horn, I. Mingareev, A, Werth, M. Kachel and U. Brenk: Investigations on Ultrafast Welding of Glass-glass and Glasssilicon, Appl. Phys. A, 93 (2008) 171.

15) I. Miyamoto, Y. Okamoto, A. Hansen, J. Vihinen, T. Amberla and J. Kangastupa: High Speed, High Strength Microwelding of Si/ glass Using Ps-laser Pulses, Opt. Express, 23 (2015) 3427.

16) Y. Ozeki, T. Inoue, T. Tamaki, H. Yamaguchi, S. Onda, W. Watanabe, T. Sano, S. Nishiuchi, A. Hirose and K. Itoh: Direct Welding between Copper and Glass Substrates with Femtosecond Laser Pulses, Appl. Phys. Express, 1 (2008) 082601.

17) H. Huan, L.M. Yang, S. Bai and J. Liu : Femtosecond Fiber Laser Welding of Dissimilar Metals, Appl. Opt., 53 (2014) 6569.

18) H. Huang, L. -M. Yang and J. Liu : Ultrashort Pulsed Fiber Laser Welding and Sealing of Transparent Materials, Appl. Opt., $5 \mathbf{l}$ (2012) 2979

19) C.B. Schaffer, J.F. Garica and E. Mazur:Bulk Heating of Transparent Materials Using a High-repetition-rate Femtosecond Laser, Appl. Phys. A, 76 (2003) 351.

20) M. Eaton, H. Zhang, P.R. Herman, F. Yoshino. L. Shah, J. Bovatsek and A.Y. Arai : Heat Accumulation Effects in Femtosecond Laser Written Waveguides with Variable Repetition Rate, Opt. Express, 13 (2005) 4708.

21) K. Cvecek, R. Odato, S. Dehmel, I. Miyamoto and M. Schmidt: Gap Bridging in Joining of Glass Using Ultra Short Laser Pulses, Opt. Express, 23 (2015) 5681

22) K. Cvecek, I. Miyamoto, J. Strauss, M. Wolf, T. Frick and M. Schmidt: Sample Preparation Method for Glass Welding by Ultrashort Laser Pulses Yields Higher Seam Strength, Appl. Opt., 50 (2011) 1941.

23) D. Hélie, M. Bégin, F. Lacroix and R. Vallée : Reinforced Direct Bonding of Optical Materials by Femtosecond Laser Welding, Appl. Opt., 51 (2012) 2098.

24) D. Helie, S. Gouin and R. Vallee : Assembling an Endcap to Optical Fibers by Femtosecond Laser, Opt. Mater. Express, 3 (2013) 1742 .

25）太田道春，篠原亘，伊東一良：第 78 回レーザ加工学会論文集, (2013) 139.

26) 米村正寿, 加藤覚, 高橋秀知, 太田道春 : 第 79 回レーザ加工学 会講演論文集, (2013) 153 .

|

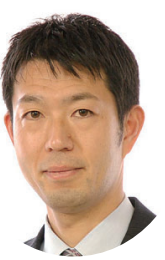

\section{渡邊 歴}

1999 年大阪大学大学院丁学研究科応用物理学曺 攻博士後期課程修了. 博士 (工学). 1999 年大 阪大学大学院工学研究科助手, 2006 年上り独立 行政法人産業技術総合研究所研究員, 主任研究 員. 2013 年より立命館大学理工学部電気電子工 学科教授. 2003 年第 44 回光学論文賞 (応用物 理学会 (日本光学会)), 2010 年文部科学省 平 成 22 年度科学技術分野の文部科学大臣表彰若手 科学者賞.

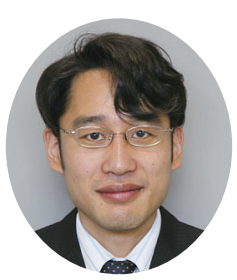

玉木隆幸

2007 年大阪大学大学院工学研究科物質 · 生命工 学専攻博士後期課程修了. 博士 (工学). 2007 年奈良工業高等専門学校電子制御工学科助教, 2010 年トロント大学（カナダ）電子情報工学専 攻訪問教授（兼任），2012 年奈良工業高等専門 学校電子制御工学科講師, 2014 年上り奈良工業 高等専門学校電子制御工学科准教授. 第 29 回応 用物理学会論文賞 (JJAP 論文奨励賞).

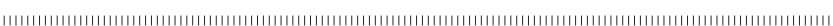

